\title{
Branje mladih leta 2009 in leta 2018 ter razlike v branju glede na spol in izobraževalni program
}

\author{
Klaudija Šterman Ivančič, Pedagoški inštitut \\ Melita Puklek Levpušček, Filozofska fakulteta Univerze v Ljubljani
}

$\mathrm{D}$ obra bralna pismenost mladih je izjemnega pomena. Ne le, da jim $\mathrm{v}$ prvi vrsti omogoča učinkovito sporazumevanje $\mathrm{z}$ drugimi in osmišljanje ter reševanje problemov v različnih življenjskih situacijah, je tudi ključni dejavnik uspešnega pridobivanja informacij, usvajanja znanja in uspešnosti na različnih področjih učenja. $\mathrm{V}$ dobi digitalizacije in ob poplavi informacij, ki so jih mladi v današnjem svetu deležni, je še toliko bolj pomembno, da imajo dobro razvite bralne spretnosti. To jim namreč omogoča, da znajo informacije kritično in analitično presoditi ter oceniti, katere med njimi so kakovostne in uporabne.

V Sloveniji bralno pismenost mladih med drugim spremljamo z raziskavo PISA, in sicer od leta 2006 naprej, ko je Slovenija v raziskavi sodelovala prvič. $\mathrm{V}$ primerjavi z matematiko in naravoslovjem, ki ju raziskava prav tako preverja, se je prav branje $\mathrm{v}$ vseh ciklih raziskave pokazalo kot šibkejše področje. Sicer so slovenski Is-letniki v povprečju OECD v večini ciklov raziskave dosegli nadpovprečne dosežke na preizkusu bralne pismenosti PISA, a hkrati poročajo o nizki motivaciji za branje, vseskozi pa so evidentne tudi precejšnje razlike med spoloma (Šterman Ivančič, 2019). Zaradi pomembnosti bralne pismenosti mladih in njenih učinkov na različna področja učenja ocenjujeva, da je nizka motivacija za branje mladih v Sloveniji problem, ki ga kaže dodatno raziskati. Ker je bila bralna pismenosti v okviru raziskave PISA kot poudarjeno področje merjenja preverjana v letih 2009 in 2018 , se v članku osredotočava na primerjalno analizo bralnih aktivnosti mladih in njihove motivacije za branje $\mathrm{v}$ teh dveh ciklih raziskave, pri čemer naju še posebej zanimajo razlike po spolu in srednješolskem izobraževalnem programu. 
V raziskavi PISA se na področju bralne pismenosti kažejo bistvene razlike po spolu že od leta 2006 naprej (Šterman Ivančič, 2019; Štraus, 2010; Štraus, Repež in Štigl, 2007; Štraus, Šterman Ivančič in Štigl, 2013 in 2017). Is-letnice $\mathrm{v}$ primerjavi s I5-letniki v povprečju dosegajo višje dosežke na preizkusu iz bralne pismenosti raziskave PISA v vseh državah OECD, razlika v dosežku med spoloma pa je v Sloveniji, primerjalno z drugimi državami, vseskozi med največjimi. Leta 20r8, ko je bilo branje nazadnje poudarjeno področje merjenja v raziskavi, je ta razlika v Sloveniji znašala 42 točk, na povprečni ravni držav OECD pa 30 točk (Šterman Ivančič, 2019).

Razlike med spoloma se kažejo tudi v motivaciji za branje. V raziskavi PISA jo ugotavljamo na podlagi časa, ki ga Is-letniki namenijo branju za zabavo, in njihovi oceni lastnega uživanja $\mathrm{v}$ branju. V raziskavi PISA 2018 je bila v Sloveniji vrednost indeksa uživanja v branju za dijake - 0,55, kar je pod povprečjem držav OECD, za dijakinje pa o,II, kar je nekoliko nad povprečjem držav OECD (Šterman Ivančič, 2019). Uživanje v branju se je $\mathrm{v}$ vseh ciklih raziskave pokazalo tudi kot statistično značilen motivacijski napovednik višjih bralnih dosežkov, pa tudi uporabe učinkovitejših bralnih strategij. Is-letniki, ki so poročali, da uživajo v branju, so hkrati poročali tudi o pogostejši uporabi učinkovitejših bralnih strategij v primerjavi s Is-letniki, ki so poročali, da v branju ne uživajo (Guthrie, Schafer in Huang, 2001; OECD, 2010; OECD, 2015). Sullivan in Brown (2015) opozarjata na povratni pozitivni učinek učinkovitosti v branju na motivacijo za branje: boljši bralci raje berejo, kar pa ponovno vodi k še hitrejšemu razvoju besedišča in večji motivaciji za branje.

Rezultati iz leta 2018 za Slovenijo kažejo tudi, da je prišlo v primerjavi z letom 2009, ko je bilo branje prav tako poudarjeno področje merjenja $\mathrm{v}$ raziskavi, tako pri dijakih kot dijakinjah do upada $\mathrm{v}$ uživanju v branju, kar je z vidika učinkovitosti branja in bralnih dosežkov zaskrbljujoče (Šterman Ivančič, 2019). Poleg tega se je med cikloma raziskave PISA 2009 in 2018 precej spremenila tudi sama narava branja, saj je minulo desetletje zaznamovala nagla digitalizacija. OECD (2019a) poroča, da je leta 2009 o tem, da doma nimajo dostopa do spleta, v povprečju poročalo približno is odstotkov Is-letnikov iz držav OECD, leta 2018 pa se je to število zmanjšalo na manj kot 5 odstotkov. V vseh državah, v katerih so Is-letniki izpolnjevali neobvezni Vprašalnik o uporabi informacijsko-komunikacijske

I V raziskavi PISA sodelujejo mladostniki, stari med is let in 3 mesece in 16 let ter 2 meseca. VSloveniji so to praviloma dijaki in dijakinje, ki obiskujejo prve letnike srednješolskih izobraževalnih programov. Ko v članku govoriva o sodelujočih v raziskavi PISA na splošno, uporabljava termin I5-letniki. Ko govoriva o vzorcu za Slovenijo, govoriva o dijakih in dijakinjah. 
tehnologije (IKT), se je v odgovorih pokazalo, da se je čas, ki ga Is-letniki preživijo na spletu zunaj šole, med letoma 2012 in 2018 podaljšal za več kot uro na dan (med delavniki in ob koncu tedna). Is-letniki zdaj med tednom preživijo na spletu v povprečju okoli 3 ure na dan in skoraj 3,5 ure na dan ob koncu tedna (ibid.). Predvidevava, da omenjeno pomembno vpliva na to, kako in na kakšne načine mladi berejo ter po kakšnem bralnem gradivu danes najraje posegajo.

Kot se je pokazalo že v preteklih analizah podatkov raziskave PISA, je v Sloveniji eden izmed pomembnejših dejavnikov bralnih dosežkov izobraževalni program, ki ga dijak obiskuje. Rezultati sekundarnih analiz raziskave PISA 2009 (Puklek Levpušček, Podlesek in Šterman Ivančič, 20I2) so pokazali, da se bralni dosežki slovenskih dijakov r. letnikov srednje šole v veliki meri razlikujejo zaradi učinka izobraževalnega programa, do razlik med izobraževalnimi programi pa je prihajalo tako $v$ individualnih značilnostih dijakov (npr. čas, ki ga dijaki dnevno namenjajo branju, zaznavanje posameznih strategij povzemanja, razumevanja in pomnjenja besedil), značilnostih domačega okolja dijakov (npr. socialnoekonomski status družin dijakov, jezik, ki ga govorijo v domačem okolju) kot šolskem okolju (spodbude učitelja pri bralnih aktivnostih, uporaba računalnika $\mathrm{v}$ šoli, pogostost interpretiranja literarnih tekstov). Kljub izrazitim razlikam med izobraževalnimi programi pa so rezultati analiz pokazali tudi, da obstajajo pomembne razlike med dijaki znotraj izobraževalnih programov, in sicer se dijaki in dijakinje znotraj programov razlikujejo v bralni aktivnosti, zanimanju za branje, stališčih do različnih strategij branja, pogostosti ukvarjanja z različnimi besedili in pogostosti rabe računalnika za bralno dejavnost.

Sekundarne analize podatkov raziskave PISA 2015 (Šterman Ivančič, 2017) so pokazale, da se dijaki in dijakinje znotraj posameznih izobraževalnih programov $\mathrm{v}$ doseganju naravoslovnih dosežkov na preizkusu PISA značilno razlikujejo tudi po spolu, vendar ne na način, kot se to kaže na povprečni ravni za Slovenijo. Na povprečni ravni države so dijakinje v letu 2015 na naravoslovnem preizkusu PISA dosegle 6 točk več kot dijaki ( 516 točk proti 5 Io točk), omenjena razlika pa je bila statistično značilna. Rezultati analiz razlik v dosežku glede na spol znotraj posameznega izobraževalnega programa pa so pokazali, da so dijaki znotraj vseh izobraževalnih programov v povprečju dosegli višji dosežek na naravoslovnem preizkusu PISA kot dijakinje.

Izobraževalni program je torej v Sloveniji specifičen kontekst, ki ga je pri pojasnjevanju dosežkov vredno upoštevati. Sekundarne analize, s katerimi bi preverili razlike po spolu v bralnih dosežkih znotraj posameznega izobraževalnega programa, do sedaj še niso bile opravljene. Ker so razlike 
med spoloma pri branju v Sloveniji med večjimi, se nama zdi to vredno nadalje raziskati. Ker pa je prišlo med leti 2009 in 2018 do pomembnih razlik v samem načinu branja mladih, se bova raje kot na same bralne dosežke osredotočili na razlike, ki se nanašajo na njihovo motivacijo za branje, vrsto gradiva, ki ga berejo, branje, ki ga opravijo na spletu, in oceno uporabnosti različnih metakognitivnih bralnih strategij. Temeljni vprašanji, na kateri želiva v tem prispevku odgovoriti, sta tako naslednji:

Ali je prišlo med leti 2009 in 2018 do sprememb $v$ motivaciji za branje, pogostosti branja določene vrste gradiva, $v$ bralnih dejavnostih na spletu in oceni uporabnosti različnih metakognitivnih bralnih strategij pri slovenskih is-letnikih?

in

Ali labko razlike med spoloma, ki se na že omenjenih področjih kažejo na nacionalni ravni, na podlagi podatkov raziskave PISA 2018 potrdimo tudi znotraj posameznih izobraževalnih programov?

\section{Metoda}

\section{Vzorec}

Za namene naše razprave sva uporabili podatke raziskav PISA 2009 in PISA 20I8, kjer so v Sloveniji vključeni vsi mladostniki, stari med is let in 3 mesece in 16 let ter 2 meseca (v nadaljevanju dijaki in dijakinje), ne glede na izobraževalni program, ki ga obiskujejo. Vzorčenje je v raziskavi PISA večstopenjsko in stratificirano, zaradi zagotavljanja reprezentativnosti vzorca po izobraževalnih programih pa so v Sloveniji vanj zajeti vsi srednješolski izobraževalni programi in nekaj naključno izbranih osnovnih šol ter institucij za izobraževanje odraslih. Načeloma velja, da znotraj določenega izobraževalnega programa iz seznama vseh is-letnikov naključno izberemo vzorec 30 dijakov in dijakinj, ki so nato vključeni v raziskavo. Sodelovanje v raziskavi je anonimno. Postopki vzorčenja in izvedba raziskave na šoli so podrobneje opisani v nacionalnem poročilu raziskav PISA 2009 (Štraus, 2010) in PISA 2018 (Šterman Ivančič, 2019).

$\mathrm{V}$ raziskavi PISA 2009 je sodelovalo 7764 dijakov in dijakinj, v letu 2018 pa 6400 dijakov in dijakinj. Ker sva analize za potrebe te študije izvedli predvsem na podatkih raziskave PISA 20I8, v nadaljevanju podrobneje opisujeva ta vzorec.

Za potrebe najine analize sva iz vzorca 6400 dijakov in dijakinj izločili I5-letnike, vključene v osnovno šolo, in tiste, ki so obiskovali programe nižjega poklicnega izobraževanja. Za slednje namreč nimamo vseh podatkov, ki jih potrebujemo za naše analize. Končni vzorec, vključen v analize, 
zajema reprezentativni vzorec 6074 I5-letnih dijakov in dijakinj, pri čemer jih je I 409 (od teh 896 oziroma $64 \%$ dijakinj in 513 oziroma $36 \%$ dijakov) obiskovalo splošno gimnazijo, 645 (od teh 357 oziroma $55 \%$ dijakinj in 288 oziroma $45 \%$ dijakov) strokovno gimnazijo, 2578 (od teh II99 oziroma 47 \% dijakinj in 1379 oziroma 53 \% dijakov) program srednjega strokovnega izobraževanja in I 442 (od teh 430 oziroma $30 \%$ dijakinj in IOI 2 oziroma $70 \%$ dijakov) program srednjega poklicnega izobraževanja.

\section{Pripomočki}

Dijaki in dijakinje so po 2-urnem preizkusu z nalogami bralne pismenosti $\mathrm{v}$ raziskavah PISA 2009 in 2018 izpolnjevali Vprašalnik za dijake in dijakinje. Izpolnjevanje le-tega traja približno 40 minut, z njim pa se v okviru raziskave ugotavljajo spremljajoči dejavniki dosežkov. Za potrebe pričujoče študije sva se $\mathrm{v}$ analizi osredotočili na vprašanja, s pomočjo katerih so dijaki in dijakinje $\mathrm{v}$ obeh ciklih raziskave ocenili čas, ki ga namenijo branju za zabavo, svoje uživanje v branju, pogostost branja določene vrste gradiva, bralne aktivnosti na spletu in uporabnost metakognitivnih bralnih strategij razumevanja, pomnjenja ter povzemanja besedila.

Čas, ki ga namenijo branju za zabavo, so dijaki in dijakinje ocenili na 5-stopenjski lestvici ( - Ne berem za zabavo do s - Več kot 2 uri na dan), pri čemer so odgovorili na vprašanje: »Približno koliko časa navadno nameniš branju za zabavo?«

$U$ živanje v branju so dijaki in dijakinje ocenili na 4-stopenjski lestvici ( $I$ - Sploh se ne strinjam do 4-Popolnoma se strinjam), ocenili pa so naslednje postavke: »Berem le, če moram «, »Branje je eden izmed mojih najljubših konjičkov«, »O knjigah se rad/-a pogovarjam z drugimi«, $\gg$ Branje se mi zdi izguba časa « in $\gg$ Berem le zato, da dobim informacije, ki jih potrebujem «.

Pogostost branja določene vrste gradiva so dijaki in dijakinje ocenili na 5-stopenjski lestvici ( $I$ - Nikoli ali skoraj nikoli do 5 - Večkrat na teden), pri čemer so ocenili pogostost branja naslednjih gradiv: $\gg$ Revije $\ll$, $\gg$ Stripi «, »Leposlovje (romani, pripovedi, zgodbe)《, »Knjige, ki niso leposlovje (informativne, dokumentarne) $\ll$ in $\gg$ Časopisi $\ll$.

Pogostost izvajanja razlicnih bralnih aktivnosti na spletu so dijaki in dijakinje ocenili na s-stopenjski lestvici ( $I-N e$ vem, kaj je to, do sVečkrat na dan), pri čemer so ocenili pogostost izvajanja naslednjih bralnih aktivnosti: »Branje elektronske pošte «, »Klepetanje prek spleta $\ll$, »Branje spletnih novic«, »Iskanje spletnih informacij o določenih vsebinah $\ll$, »Sodelovanje v skupinskih razpravah ali forumih na spletu« in »Iskanje uporabnih informacij na spletu«. 
Uporabnost različnih metakognitivnih bralnih strategij razumevanja in pomnjenja besedila so dijaki in dijakinje ocenili na 6-stopenjski lestvici ( $I$ - Sploh ni uporabna do 6 - Zelo uporabna), pri čemer so ocenili uporabnost naslednjih bralnih strategij: »Osredotočim se na dele besedila, ki jih z lahkoto razumem «, »Dvakrat hitro preberem besedilo«, $\gg$ Po tem, ko preberem besedilo, se o njegovi vsebini pogovarjam z drugimi $\ll$, $\gg$ Podčrtam pomembne dele besedila «, $\gg S$ svojimi besedami povzamem besedilo $\ll$ in $\gg$ Besedilo na glas preberem nekomu drugemu $\ll$.

Uporabnost različnih metakognitivnih bralnih strategij povzemanja besedila so prav tako ocenili na 6-stopenjski lestvici ( - - Sploh ni uporabna do 6 -Zelo uporabna), pri čemer so ocenili uporabnost naslednjih bralnih strategij: »Napišem povzetek. Nato preverim, ali je vsak odstavek vključen $\mathrm{v}$ povzetek, ker mora biti vključena vsebina vsakega odstavka«, »Pravilno poskušam prepisati čim več stavkov«, »Preden napišem povzetek, čim večkrat preberem besedilo «, $\gg$ Natančno preverim, ali so v povzetku predstavljena najpomembnejša dejstva « in »Preberem besedilo in podčrtam najpomembnejše stavke. Nato jih s svojimi besedami napišem kot povzetek «.

Vse uporabljene lestvice so se na vzorcu slovenskih dijakov in dijakinj, ki so sodelovali v raziskavi PISA 20I8, izkazale kot ustrezno notranje zanesljive, in sicer so se vrednosti koeficientov notranje zanesljivosti gibale med $\alpha=0,67$ in $\alpha=0,85$ (OCED, 2020, in osebni izračuni).

\section{Obdelava podatkov}

Podatke sva analizirali s pomočjo statističnega programa IBM SPSS 27.0 in orodja IEA IDBAnalyzer Version 4.0.35, ki nam pri obravnavi podatkov zaradi dvostopenjskega vzorčenja $\mathrm{v}$ raziskavi poleg uporabe uteži za posameznega učenca (W_FSTUWT) omogoča tudi uporabo vzorčnih uteži z namenom ustrezne ocene standardne napake parametrov v populaciji po metodi ponovnega vzorčenja (ang. Bootstrap).

Pri odgovarjanju na prvo raziskovalno vprašanje sva uporabili odstotne deleže odgovorov na posamezno postavko, pripadajoči povprečni bralni dosežek ter podatek o statistični značilnosti razlik med deleži odgovorov na posamezni postavki med leti 2009 in 2018 . Te podatke sva za leto 2009 delno pridobili iz sekundarnih analiz raziskave PISA 2009 (Puklek Levpušček et al., 20I2), delno pa iz mednarodnega poročila raziskave (OECD, 20I0). Za leto 2018 sva podatke prav tako pridobili iz mednarodnega poročila (OECD, 2019b).

$\mathrm{V}$ okviru drugega raziskovalnega vprašanja sva najprej izračunali povprečne vrednosti in standardne odklone za posamezno vključeno postavko; izračunali sva jih ločeno glede na spol znotraj vsakega posameznega 
izobraževalnega programa. Ker naju je zanimalo, ali so razlike med spoloma znotraj vsakega izobraževalnega programa statistično značilne, sva v naslednjem koraku izračunali tudi vrednost $t$-testa pri stopnji tveganja $p$ $\leq 0,05$.

\section{Rezultati in razprava}

\section{Branje za zabavo}

Pri ugotavljanju razlik v motivaciji za branje med leti 2009 in 2018 se najprej osredotočava na čas, ki ga slovenski dijaki in dijakinje namenijo branju za zabavo. Leta 2009 je bilo dijakov in dijakinj, ki so poročali, da ne berejo za zabavo, približno $40 \%$, v letu 2018 pa $50 \%$ (Tabela I). Tistih dijakov in dijakinj, ki so poročali, da po navadi berejo trideset minut ali manj na dan, je bilo v letu 2018 za približno I3 odstotnih točk manj kot v letu 2009. Iz mednarodnega poročila raziskave PISA 2018 (OECD, 2019b) je razvidno, da so omenjene razlike statistično značilne.

Tabela ı: Odstotek odgovorov na vprašanje »Približno koliko časa navadno nameniš branju za zabavo? « ter povprečni bralni dosežki dijakov: primerjava med leti 2009 in 2018.

\begin{tabular}{|c|c|c|c|c|c|}
\hline & $\begin{array}{l}\text { Ne berem } \\
\text { za zabavo. }\end{array}$ & $\begin{array}{l}30 \text { minut } \\
\text { ali manj } \\
\text { na dan. }\end{array}$ & $\begin{array}{l}\text { Več kot } 30 \\
\text { minut in } \\
\text { manj kot } \\
60 \text { minut } \\
\text { na dan. }\end{array}$ & $\begin{array}{l}\text { Od I do } \\
2 \text { uri na } \\
\text { dan. }\end{array}$ & $\begin{array}{l}\text { Več kot } \\
2 \text { uri na } \\
\text { dan. }\end{array}$ \\
\hline \% dijakov in dijakinj ${ }^{*}(2009)$ & 39,8 & 34,5 & 15,6 & 8,0 & 2,2 \\
\hline Bralni dosežek ${ }^{* *}$ & 446 & 499 & 526 & 520 & 521 \\
\hline \% dijakov in dijakinj ${ }^{*}(2018)$ & 49,5 & 21,9 & 14,4 & 9,3 & $4, \mathrm{I}$ \\
\hline Bralni dosežek ${ }^{* *}$ & 468 & 521 & 528 & 538 & 524 \\
\hline
\end{tabular}

Opomba: * Odstotek dijakov in dijakinj, ki so določeno postavko označili. Navodilo je zahtevalo, da respondent označi en odgovor; **Povprečni dosežek za Slovenijo pri branju je leta 2009 znašal 483 točk (OECD 494 točk), leta 2018 pa 495 točk (OECD 487 točk).

Zaradi večje preglednosti v tabeli ne navajamo vrednosti standardnih odklonov. Ta podatek je dostopen v pripadajoči tabeli na naslednji povezavi pod zavihkom Codebook and Compendia: https://www.oecd.org/pisa/data/2or8database/.

Čas, ki ga slovenski dijaki in dijakinje namenijo branju za zabavo, se je v obdobju desetih let torej zmanjšal, kar je z vidika motivacije za branje in bralnih dosežkov neugoden podatek. Že rezultati sekundarnih analiz 
na podatkih iz leta 2009 (Puklek Levpušček et al., 2012) so pokazali, da je za razvijanje bralne pismenosti in bralne dosežke mladih pomembno, da ti branje sprejmejo kot dejavnost, ki jo v prostem času radi počnejo, in vsakodnevno posvetijo vsaj nekaj minut prostočasnemu branju. V letu 2009 so najvišji povprečni dosežek na preizkusu iz bralne pismenosti PISA namreč dosegli prav dijaki in dijakinje, ki so poročali, da po navadi berejo med 30 in 60 minutami na dan. V letu 2018 so najvišje povprečne dosežke dosegli dijaki in dijakinje, ki so poročali, da po navadi berejo eno do dve uri, kar je lahko tudi pokazatelj bolj redkega poseganja mladih po bralnem gradivu in slabših bralnih spretnostih.

Znotraj vseh štirih izobraževalnih programov so dijakinje v večji meri poročale, da v povprečju namenijo več časa branju za zabavo kot dijaki. Razlike med spoloma so statistično značilne (Tabela 2). V splošnem rezultati kažejo, da za zabavo največ berejo dijaki in dijakinje, ki obiskujejo gimnazijske programe, manj dijaki in dijakinje, ki obiskujejo srednje strokovno izobraževanje, najmanj pa dijaki in dijakinje, ki obiskujejo srednje poklicno izobraževanje.

Tabela 2: Povprečni čas, namenjen branju za zabavo: razlike po spolu znotraj posameznih izobraževalnih programov v letu 2018.

\begin{tabular}{|c|c|c|c|c|c|}
\hline & & \multicolumn{4}{|c|}{ Čas, namenjen branju za zabavo } \\
\hline & & $M$ & $S D$ & $t(\mathrm{df})$ & $p$ \\
\hline \multirow{2}{*}{ Splošna in klasična gimnazija } & Dijaki & $\mathrm{I}, 87$ & 1,09 & & \\
\hline & Dijakinje & 2,25 & $\mathrm{I}, 2 \mathrm{I}$ & $8,4 \circ(\mathrm{I} 388)$ & *** \\
\hline \multirow{2}{*}{ Strokovna gimnazija } & Dijaki & I,83 & $\mathrm{I}, \mathrm{O4}$ & & \\
\hline & Dijakinje & 2,53 & $\mathrm{I}, 28$ & $6,60(638)$ & *** \\
\hline \multirow{2}{*}{ Srednje strokovno izobraževanje } & Dijaki & 1,50 & 0,91 & & \\
\hline & Dijakinje & $2, \mathrm{II}$ & $\mathrm{I}, 25$ & II,9I (2537) & **** \\
\hline \multirow{2}{*}{ Srednje poklicno izobraževanje } & Dijaki & $\mathrm{I}, 44$ & 0,89 & & \\
\hline & Dijakinje & 1,94 & 1,20 & $6,37(\mathrm{I} 39 \mathrm{I})$ & **** \\
\hline
\end{tabular}

Opomba: Dijaki in dijakinje so na vprašanje odgovorili na lestvici od I do 5 , kjer i pomeni, da ne berejo za zabavo, 5 pa, da za zabavo berejo več kot 2 uri na dan; $M$ - aritmetična sredina; $S D$ - standardni odklon; $t$ - t test; $d f$ - stopnje svobode; $p$ - stopnja tveganja: ${ }^{* * *} \mathrm{p} \leq, \mathrm{O}$ I.

\section{Uživanje v branju}

Naslednji pokazatelj, s katerim v raziskavi PISA ugotavljamo motivacijo I5-letnikov za branje, je njihova ocena lastnega uživanja v branju. Leta 2009 se je $53 \%$ dijakov in dijakinj strinjalo ali popolnoma strinjalo s tem, da berejo le, če morajo (Tabela 3 ). Leta 2018 je o tem poročalo za 3 odstotne točke več dijakov in dijakinj, iz mednarodnega poročila raziskave PISA 
2018 (OECD, 2019b) pa je razvidno, da je omenjena razlika med leti statistično značilna. Iz mednarodnih podatkov (ibid.) je razvidno tudi, da se je pri tem med leti 2009 in $2018 \mathrm{v}$ Sloveniji značilno zvišal predvsem delež dijakinj, ki so se strinjale s trditvijo, da berejo le, če morajo, in sicer za 6 odstotnih točk. Že v primerjalni analizi slovenskih rezultatov dijakov in dijakinj v raziskavi PISA $2009 \mathrm{z}$ rezultati skandinavskih I5-letnikov smo ugotovili, da je za slovenske dijake in dijakinje značilen vzorec branja predvsem zaradi zunanje motivacije ( $\mathrm{tj}$. ker morajo brati ali da dobijo potrebne informacije) (Puklek Levpušček, Podlesek in Šterman Ivančič, 2013). Tudi po desetih letih tako še vedno ostaja izziv, kako v slovenskih šolah krepiti notranji interes za branje, ki ga lahko spodbujamo tudi s pristopi k poučevanju, ki v večji meri upoštevajo bralna zanimanja mladostnikov.

Tabela 3: Odstotek dijakov, ki so na trditve o uživanju v branju odgovorili s »Strinjam se « in »Popolnoma se strinjam «, ter njihovi povprečni bralni dosežki: primerjava med leti 2009 in 2018.

\begin{tabular}{|c|c|c|c|c|c|}
\hline & $\begin{array}{c}\text { Berem le, če } \\
\text { moram. }\end{array}$ & $\begin{array}{c}\text { Branje je } \\
\text { eden izmed } \\
\text { mojih } \\
\text { najljubših } \\
\text { konjičkov. }\end{array}$ & $\begin{array}{l}\text { O knjigah } \\
\text { se rad/-a } \\
\text { pogovarjam } \\
\text { z drugimi. }\end{array}$ & $\begin{array}{c}\text { Branje se mi } \\
\text { zdi izguba } \\
\text { časa. }\end{array}$ & $\begin{array}{c}\text { Berem le } \\
\text { zato, da } \\
\text { dobim } \\
\text { informacije, } \\
\text { ki jih } \\
\text { potrebujem. }\end{array}$ \\
\hline \% dijakov in dijakinj (2009) & 52,8 & 23,2 & 34,5 & 33,4 & $53, \mathrm{I}$ \\
\hline Bralni dosežek ${ }^{*}$ & 455 & 529 & 524 & 446 & 460 \\
\hline \% dijakov in dijakinj (20I8) & 56,4 & 25,5 & 33,0 & 36,3 & 52,7 \\
\hline Bralni dosežek* & 474 & 537 & 532 & 456 & $47 \mathrm{I}$ \\
\hline
\end{tabular}

Opomba: * Gre za povprečni dosežek tistih dijakov in dijakinj, ki so na postavko odgovorili $s \gg$ Strinjam se $\ll$ in $s \gg$ Popolnoma se strinjam «; Povprečni dosežek za Slovenijo pri branju je leta 2009 znašal 483 točk (OECD 494 točk), leta 2018 pa 495 točk (OECD 487 točk).

Zaradi večje preglednosti v tabeli ne navajamo vrednosti standardnih odklonov. Ta podatek je dostopen v pripadajoči tabeli na naslednji povezavi pod zavihkom Codebook and Compendia: https://www.oecd.org/pisa/data/2or8database/.

Rezultati (Tabela 3 in OECD, 2019b) nadalje kažejo, da se je v Sloveniji značilno povečal tudi delež dijakov in dijakinj, ki so leta 2018 poročali, da se strinjajo ali popolnoma strinjajo s tem, da se jim zdi branje izguba časa (približno 3 odstotne točke več kot leta 2009), hkrati pa se je značilno povečal delež tistih, ki menijo, da je branje eden izmed njihovih najljubših konjičkov (približno 3 odstotne točke več kot leta 2009). Pri 
obeh omenjenih postavkah se je med leti 2009 in 2018 značilno povečal predvsem delež dijakov (za 4 odstotne točke pri oceni branja kot izgube časa in za 3 odstotne točke pri oceni branja kot najljubšega konjička). Pri odgovorih na ostale postavke med leti 2009 in 2018 ni prišlo do značilnih sprememb v odstotnih deležih.

Tako v letu 2009 kot 2018 so najvišji povprečni dosežek na preizkusu iz bralne pismenosti PISA dosegli tisti dijaki in dijakinje, ki so se strinjali s tem, da je branje eden izmed njihovih najljubših konjičkov (Tabela 3). Rezultati analiz razlik glede na izobraževalni program in spol (Tabela 4) kažejo, da so se s to trditvijo v povprečju najbolj strinjali dijaki in dijakinje iz gimnazijskih programov, najmanj pa dijaki in dijakinje iz programov srednjega poklicnega izobraževanja. Znotraj vseh navedenih izobraževalnih programov so se $s$ to trditvijo $v$ večji meri strinjale dijakinje, razlika med spoloma znotraj programov pa se je povsod pokazala kot statistično značilna.

Tabela 4: Ocena branja kot enega izmed najjubših konjičkov: razlike po spolu znotraj posameznih izobraževalnih programov v letu 2018.

\begin{tabular}{|c|c|c|c|c|c|}
\hline & & \multicolumn{4}{|c|}{ Branje kot najljubši konjiček } \\
\hline & & $M$ & $S D$ & $t(\mathrm{df})$ & $p$ \\
\hline \multirow{2}{*}{ Splošna in klasična gimnazija } & Dijaki & 1,93 & 0,90 & & \\
\hline & Dijakinje & $2,5 \mathrm{I}$ & 0,98 & $9,56(1385)$ & *** \\
\hline \multirow{2}{*}{ Strokovna gimnazija } & Dijaki & $\mathrm{I}, 84$ & 0,77 & & \\
\hline & Dijakinje & 2,40 & 0,94 & $7,40(634)$ & **** \\
\hline \multirow{2}{*}{ Srednje strokovno izobraževanje } & Dijaki & $\mathrm{I}, 66$ & 0,77 & & \\
\hline & Dijakinje & 2,02 & 0,96 & $8,65(253 \mathrm{I})$ & *** \\
\hline \multirow{2}{*}{ Srednje poklicno izobraževanje } & Dijaki & $\mathrm{I}, 6 \mathrm{I}$ & $0,8 \circ$ & & \\
\hline & Dijakinje & $\mathrm{I}, 88$ & 0,87 & $4,8 \mathrm{I}(\mathrm{I} 390)$ & *** \\
\hline
\end{tabular}

Opomba: Dijaki in dijakinje so postavko ocenili na lestvici od I do 4, kjer I pomeni, da se sploh ne strinjajo s tem, da je branje eden izmed njihovih najjubšsih konjičkov, 4 pa, da se s tem popolnoma strinjajo; $M$ - aritmetična sredina; $S D$ - standardni odklon; $t$ - t test; $d f$ - stopnje svobode; $p$ - stopnja tveganja: ${ }^{* * *} \mathrm{p} \leq, \mathrm{oor}$.

\section{Vrsta bralnega gradiva}

Naslednji dejavnik, ki se je v raziskavi PISA 2009 že pokazal kot značilen napovednik bralnih dosežkov is-letnikov, je vrsta bralnega gradiva, po katerem ti najpogosteje posegajo. Pri tem je prišlo med leti 2009 in 2018 do največjih razlik pri pogostosti branja revij in časopisov, pa tudi stripov (Tabela 5). Dijaki in dijakinje so v letu 2018 poročali o precej manj pogostem branju te vrste gradiv: o mesečnem oziroma tedenskem branju revij 
in časopisov je v letu $2018 \mathrm{v}$ primerjavi z letom 2009 poročalo kar za 50 odstotnih točk manj dijakov in dijakinj, o branju stripov pa za 7 odstotnih točk manj dijakov in dijakinj. Tudi branje knjig, ki niso leposlovje, se je v letu $2018 \mathrm{v}$ primerjavi z letom 2009 zmanjšalo za 3 odstotne točke. Nasprotno pa so dijaki in dijakinje leta $2018 \mathrm{v}$ primerjavi z letom 2009 poročali o nekoliko pogostejšem branju leposlovja (za 3 odstotne točke). Iz mednarodnega poročila raziskave PISA 2018 (OECD, 2019b) je razvidno, da so vse navedene razlike v odstotnih deležih med leti 2009 in 2018 statistično značilne.

Tabela s: Odstotek dijakov, ki berejo bralno gradivo »večkrat na mesec « ali »večkrat na teden «, ter njihovi povprečni bralni dosežki: primerjava med leti 2009 in 2018.

\begin{tabular}{lccccc} 
& Revije & Stripi & $\begin{array}{c}\text { Leposlovje } \\
\text { (romane, } \\
\text { pripovedi, } \\
\text { zgodbe) }\end{array}$ & $\begin{array}{c}\text { Knjige, ki niso } \\
\text { leposlovje } \\
\text { (informativne, } \\
\text { dokumentarne) }\end{array}$ & Časopisi \\
\% dijakov in dijakinj(2009) & 72,6 & 14,8 & 15,4 & 16,3 & 71,7 \\
Bralni dosežek* & $49 \mathrm{I}$ & 474 & 538 & 527 & 488 \\
\hline \% dijakov in dijakinj(2018) & 22,2 & 7,9 & 18,4 & 13,2 & 21,0 \\
Bralni dosežck* & 495 & 489 & 547 & $51 \mathrm{II}$ & 492 \\
\hline
\end{tabular}

Opomba: ${ }^{*}$ Gre za povprečni dosežek tistih dijakov in dijakinj, ki so na postavko odgovorili z »večkrat na mesec « in z »večkrat na teden «; Povprečni dosežek za Slovenijo pri branju je leta 2009 znašal 483 točk (OECD 494 točk), leta 2018 pa 495 točk (OECD 487 točk).

Zaradi večje preglednosti v tabeli ne navajamo vrednosti standardnih odklonov. Ta podatek je dostopen v pripadajoči tabeli na naslednji povezavi pod zavihkom Codebook and Compendia: https://www.oecd.org/pisa/data/2or8database/.

Primerjava rezultatov s področja branja določene vrste gradiva med leti 2009 in 2018 torej kaže na določene spremembe $\mathrm{v}$ branju mladih, trend, da sedaj berejo nekoliko več leposlovja, pa je spodbuden. Rezultati analiz podatkov iz leta 2009 (Puklek Levpušček et al., 20I2) so pokazali, da so najvišje bralne dosežke na testu PISA v Sloveniji dosegli tisti dijaki in dijakinje, ki so poročali o pogostejšem branju leposlovja. Branje daljših in kompleksnejših besedil je torej povezano z boljšo bralno kompetentnostjo in je s tega vidika ugodno, da kljub porastu digitalnih informacij ni prišlo do upada v branju daljših leposlovnih gradiv. 
Tabela 6: Pogostost branja leposlovja: razlike po spolu znotraj posameznih izobraževalnih programov v letu 2018.

\begin{tabular}{|c|c|c|c|c|c|}
\hline & & \multicolumn{4}{|c|}{ Branje leposlovja } \\
\hline & & $M$ & $S D$ & $t(\mathrm{df})$ & $p$ \\
\hline \multirow{2}{*}{ Splošna in klasična gimnazija } & Dijaki & 2,40 & 1,09 & & \\
\hline & Dijakinje & 3,08 & $\mathrm{I}, \mathrm{I} 8$ & $8,83(1389)$ & *** \\
\hline \multirow{2}{*}{ Strokovna gimnazija } & Dijaki & 2,34 & 1,09 & & \\
\hline & Dijakinje & 2,96 & $\mathrm{I}, \mathrm{I} 8$ & $6,20(636)$ & *** \\
\hline \multirow{2}{*}{ Srednje strokovno izobraževanje } & Dijaki & $\mathrm{I}, 86$ & 0,98 & & \\
\hline & Dijakinje & 2,45 & $\mathrm{I}, \mathrm{I} 6$ & $10,59(253 \mathrm{I})$ & **** \\
\hline \multirow{2}{*}{ Srednje poklicno izobraževanje } & Dijaki & $\mathrm{I}, 68$ & 0,95 & & \\
\hline & Dijakinje & $2,2 \mathrm{I}$ & $\mathrm{I}, 20$ & $7,27(1384)$ & *** \\
\hline
\end{tabular}

Opomba: Dijaki in dijakinje so postavko ocenili na lestvici od I do 5 , kjer I pomeni, da nikoli ali skoraj nikoli ne berejo leposlovja, 5 pa, da leposlovje berejo večkrat na teden; $M$ - aritmetična sredina; $S D$ standardni odklon; $t$ - t test; $d f$ - stopnje svobode; $p$ - stopnja tveganja: ${ }^{* * *} \mathrm{p} \leq, \mathrm{OOI}$.

Tabela 7: Pogostost branja knjig, ki niso leposlovje: razlike po spolu znotraj posameznih izobraževalnih programov v letu 2018.

\begin{tabular}{|c|c|c|c|c|c|}
\hline & & \multicolumn{4}{|c|}{ Branje knjig, ki niso leposlovje } \\
\hline & & $M$ & $S D$ & $t(\mathrm{df})$ & $\mathrm{p}$ \\
\hline \multirow{2}{*}{ Splošna in klasična gimnazija } & Dijaki & 2,39 & $\mathrm{I}, 2 \mathrm{I}$ & & \\
\hline & Dijakinje & 2,20 & $\mathrm{I}, \mathrm{I} 4$ & $2,24($ I391 $)$ & *** \\
\hline \multirow{2}{*}{ Strokovna gimnazija } & Dijaki & 2,36 & $\mathrm{I}, 20$ & & \\
\hline & Dijakinje & 2,07 & 0,99 & $3,46(64 \mathrm{I})$ & **** \\
\hline \multirow{2}{*}{ Srednje strokovno izobraževanje } & Dijaki & 2,08 & $\mathrm{I}, \mathrm{I} 4$ & & \\
\hline & Dijakinje & 1,91 & $\mathrm{I}, \mathrm{O} 4$ & $3,13(2536)$ & *** \\
\hline \multirow{2}{*}{ Srednje poklicno izobraževanje } & Dijaki & $\mathrm{I}, 85$ & $\mathrm{I}, \mathrm{IO}$ & & \\
\hline & Dijakinje & 1,76 & 0,99 & $\mathrm{I}, 4 \mathrm{I}(\mathrm{I} 394)$ & $>, 05$ \\
\hline
\end{tabular}

Opomba: Dijaki in dijakinje so postavko ocenili na lestvici od $\mathrm{I}$ do 5, kjer I pomeni, da nikoli ali skoraj nikoli ne berejo knjig, ki niso leposlovje, 5 pa, da te knjige berejo večkrat na teden; $M$ - aritmetična sredina; $S D$ - standardni odklon; $t$ - test; $d f$ - stopnje svobode; p-stopnja tveganja: ${ }^{* *} \mathrm{p} \leq, \mathrm{O}$ I.

Analiza razlik po izobraževalnem programu in spolu $\mathrm{v}$ pogostosti branja leposlovja in knjig, ki niso leposlovje (tabeli 6 in 7), kaže, da je tako branje leposlovja, kot knjig, ki niso leposlovje, med dijaki in dijakinjami najpogostejše v programih splošne in strokovne gimnazije, manj pa v 
programih srednjega strokovnega in poklicnega izobraževanja. Leposlovje znotraj vseh izobraževalnih programov pogosteje berejo dijakinje, kar pa ne velja za branje knjig, ki niso leposlovje. O pogostejšem branju slednjih so v vseh izobraževalnih programih poročali dijaki. Razlike med spoloma so se pokazale kot statistično značilne znotraj vseh izobraževalnih programov, razen v programu srednjega poklicnega izobraževanja, kjer v pogostosti branja knjig, ki niso leposlovje, ni statistično značilnih razlik.

\section{Dejavnosti branja na spletu}

Ker se je pogostost uporabe spleta med leti 2009 in 2018 med mladimi znatno povečala (OECD, 20I9a), naju v nadaljevanju zanima pogostost ukvarjanja 15 -letnikov z različnimi bralnimi aktivnostmi na spletu. Leta 2009 je $70 \%$ dijakov in dijakinj poročalo (Tabela 8), da večkrat tedensko ali dnevno berejo elektronsko pošto. V letu 2018 je o tem poročalo $34 \%$ dijakov in dijakinj. $V$ tem obdobju se je po poročanju dijakov in dijakinj zmanjšala tudi njihova pogostost branja spletnih novic (I 4 odstotnih točk manj $\mathrm{v}$ letu 2018) in pogostost sodelovanja $\mathrm{v}$ skupinskih razpravah in forumih na spletu (I 4 odstotnih točk manj v letu 2018). Nasprotno so dijaki in dijakinje leta 2018 poročali o pogostejšem iskanju uporabnih informacij na spletu (27 odstotnih točk več) in iskanju spletnih informacij o določenih vsebinah ( 5 odstotnih točk več). Pogostost klepetanja prek spleta je med leti 2009 in 2018 ostala dokaj nespremenjena, in sicer je približno $83 \%$ dijakov in dijakinj v obeh letih poročalo, da to počnejo na tedenski ali dnevni ravni. Iz mednarodnega poročila raziskave PISA 2018 (OECD, 2019b) je razvidno, da so vse navedene razlike v odstotnih deležih med leti 2009 in 2018 statistično značilne.

Tako leta 2009 kot 2018 (Tabela 8) so najnižji povprečni dosežek na preizkusu iz bralne pismenosti PISA dosegli tisti dijaki in dijakinje, ki so poročali, da večkrat tedensko ali dnevno sodelujejo v skupinskih razpravah ali forumih na spletu, najvišje pa tisti, ki so poročali, da splet na tedenski ali dnevni ravni uporabljajo za branje elektronske pošte, iskanje spletnih informacij o določenih vsebinah in iskanje uporabnih informacij na spletu. Tedensko ali dnevno udejstvovanje v različnih bralnih aktivnostih na spletu (razen sodelovanja v skupinskih razpravah ali forumih) je ne glede na vrsto aktivnosti $v$ obeh letih torej sovpadalo z nadpovprečnimi bralnimi dosežki na preizkusu iz bralne pismenosti PISA oziroma so se aktivnosti na spletu v letu $2018 \mathrm{v}$ povprečju povezovale celo z nekoliko višjimi dosežki na preizkusu PISA. Slednje je lahko pokazatelj tega, da mladi splet vedno bolj uporabljajo kot vir, s pomočjo katerega se učijo, in na nek način tudi krepijo svoje bralne spretnosti. Tudi sam preizkus raziskave PISA 2018 je bil v primerjavi z letom 2009 izveden na računalniku, 
torej v obliki, ki je mladim danes morda bližje, in so morda tudi zaradi tega uspešneje reševali preizkus.

Tabela 8: Odstotek dijakov, ki se ukvarjajo z različnimi bralnimi aktivnostmi na spletu »večkrat na teden « ali »večkrat na dan «, ter njihovi povprečni bralni dosežki: primerjava med leti 2009 in 2018.

\begin{tabular}{lcccccc} 
& $\begin{array}{c}\text { Branje } \\
\text { elektronske } \\
\text { pošte. }\end{array}$ & $\begin{array}{c}\text { Klepetanje } \\
\text { prek spleta. }\end{array}$ & $\begin{array}{c}\text { Branje } \\
\text { spletnih } \\
\text { novic. }\end{array}$ & $\begin{array}{c}\text { Iskanje } \\
\text { spletnih } \\
\text { informacij } \\
\text { odoločenih } \\
\text { vsebinah. }\end{array}$ & $\begin{array}{c}\text { Sodelovanje } \\
\text { vskupinskih } \\
\text { razpravah } \\
\text { ali forumih } \\
\text { na spletu. }\end{array}$ & $\begin{array}{c}\text { Iskanje } \\
\text { informacih } \\
\text { na spletu. }\end{array}$ \\
$\begin{array}{l}\text { \% dijakov in dijakinj } \\
\text { (2009) }\end{array}$ & 70,4 & 83,2 & 58,8 & 49,2 & 29,3 & 37,3 \\
Bralni dosežek* & 496 & 493 & 491 & 493 & 483 & 492 \\
\hline $\begin{array}{l}\text { \% dijakovin dijakinj } \\
\text { (20I8) }\end{array}$ & 33,9 & 83,5 & 44,8 & 54,0 & 15,9 & 64,0 \\
Bralni dosežek* & 516 & 506 & 509 & 516 & 487 & 514 \\
\hline
\end{tabular}

Opomba: * Gre za povprečni dosežek tistih dijakov in dijakinj, ki so na postavko odgovorili $z$ »večkrat na teden « in z »večkrat na dan «; Povprečni dosežek za Slovenijo pri branju je leta 2009 znašal 483 točk (OECD 494 točk), leta 2018 pa 495 točk (OECD 487 točk).

Zaradi večje preglednosti v tabeli ne navajamo vrednosti standardnih odklonov. Ta podatek je dostopen v pripadajoči tabeli na naslednji povezavi pod zavihkom Codebook and Compendia: https://www.oecd.org/pisa/data/2or8database/.

$\mathrm{V}$ aktivnostih na spletu tudi ne zaznamo značilnih razlik med spoloma. O največji pogostosti iskanja spletnih informacij so poročali dijaki in dijakinje iz gimnazijskih programov, najmanj pa dijaki in dijakinje, ki obiskujejo program srednjega poklicnega izobraževanja (Tabela 9). V gimnazijskih programih in programu srednjega poklicnega izobraževanja so dijakinje sicer poročale o nekoliko pogostejšem iskanju spletnih informacij na spletu, vendar se razlike med spoloma znotraj izobraževalnih programov niso pokazale kot statistično značilne. Ta rezultat, podobno kot leta 2009 (Puklek Levpušček et al., 2012), kaže na to, da bi tekom poučevanja $\mathrm{z}$ vidika spodbujanja motivacije za branje pri dijakih veljalo okrepiti kakovostne in zanimive spletne vsebine. 
Tabela 9: Pogostost iskanja spletnih informacij: razlike po spolu znotraj posameznih izobraževalnih programov v letu 2018.

\begin{tabular}{llllll} 
& & \multicolumn{5}{c}{ Iskanje spletnih informacij o določenih } \\
\cline { 2 - 6 } Splošna in klasična gimnazija & \multicolumn{5}{c}{ vsebinah } \\
\cline { 2 - 6 } & Dijaki & 3,84 & 0,04 & \\
\cline { 2 - 6 } Strokovna gimnazija & Dijakinje & 3,86 & 0,03 & $0,25(\mathrm{I} 39 \mathrm{I})$ & $>, 05$ \\
\hline \multirow{2}{*}{ Srednje strokovno izobraževanje } & Dijaki & 3,67 & 0,05 & \\
\cline { 2 - 6 } & Dijakinje & 3,72 & 0,08 & $0,58(637)$ & $>, 05$ \\
\hline \multirow{2}{*}{ Srednje poklicno izobraževanje } & Dijaki & 3,56 & 0,03 & $0,33(253 \mathrm{I})$ & $>, 05$ \\
\cline { 2 - 6 } & Dijakinje & 3,55 & 0,03 & & \\
\cline { 2 - 6 } & Dijaki & 3,27 & 0,05 & & \\
\hline
\end{tabular}

Opomba: Dijaki in dijakinje so postavko ocenili na lestvici od I do 5 , kjer I pomeni, da ne vedo, kaj to je, 5 pa, da spletne informacije iščejo večkrat na dan; $M$ - aritmetična sredina; $S D$ - standardni odklon; $t$ - t test; $d f$ - stopnje svobode; $p$ - stopnja tveganja.

\section{Metakognitivne bralne strategije: razumevanje in pomnjenje} besedila

Dijaki in dijakinje so, podobno kot v ciklu raziskave PISA 2009, tudi v letu 2018 ocenili uporabnost določenih metakognitivnih bralnih strategij razumevanja in pomnjenja besedila (Tabela II). V letu 2018 so dijaki in dijakinje, podobno kot leta 2009 , kot najuporabnejši bralni strategiji ocenili podčrtavanje pomembnih delov besedila in povzemanje besedila s svojimi besedami. Delež tistih, ki so omenjeni strategiji ocenili kot uporabni ali zelo uporabni, je med leti 2009 in 2018 nekoliko upadel (za 3 odstotne točke pri oceni uporabnosti podčrtavanja besedila in za 2 odstotni točki pri oceni uporabnosti povzemanja besedila). V primerjavi z letom 2009 so dijaki in dijakinje kot nekoliko uporabnejše ocenili strategije ponovnega hitrega prebiranja besedila (za 3 odstotne točke več), pogovarjanja o prebranem z drugimi (za 5 odstotnih točk več) in glasnega branja besedila drugim (za 4 odstotne točke več). Iz mednarodnega poročila raziskave PISA 2018 (OECD, 2019b) je razvidno, da so navedene razlike v odstotnih deležih med leti 2009 in 2018 statistično značilne.

Tako leta 2009 kot leta 2018 so najvišje povprečne dosežke na preizkusu iz bralne pismenosti PISA dosegli tisti dijaki in dijakinje, ki so kot najuporabnejšo bralno strategijo ocenili pogovarjanje o prebranem z drugimi. Glede na to, da je o uporabnosti te bralne strategije poročalo le približno $30 \%$ slovenskih dijakov in dijakinj, rezultati, podobno kot leta 
2009, še vedno kažejo na to, v slovenskem izobraževanju umanjka socialni kontekst branja.

Pogovarjanje o prebranem $\mathrm{z}$ drugimi so kot najuporabnejšo bralno strategijo ocenili dijaki in dijakinje v gimnazijskih izobraževalnih programih (Tabela I2), najmanj pa dijaki in dijakinje, ki obiskujejo programe srednjega poklicnega izobraževanja. Znotraj vseh izobraževalnih programov so to strategijo kot bolj uporabno ocenile dijakinje, razlike v oceni med spoloma pa so se povsod pokazale kot statistično značilne.

Tabela ıo: Odstotek dijakov, ki so ocenili, da se jim zdi določena strategija razumevanja in pomnjenja besedila $\gg$ uporabna $\ll$ ali $\gg z e l o$ uporabna «, ter njihovi povprečni bralni dosežki: primerjava med leti 2009 in 2018.

\begin{tabular}{|c|c|c|c|c|c|c|}
\hline & $\begin{array}{l}\text { Osredotočim } \\
\text { se na dele } \\
\text { besedila, ki } \\
\text { jih z lahkoto } \\
\text { razumem. }\end{array}$ & $\begin{array}{c}\text { Dvakrat } \\
\text { hitro } \\
\text { preberem } \\
\text { besedilo. }\end{array}$ & $\begin{array}{c}\text { Po tem, ko } \\
\text { preberem } \\
\text { besedilo, se } \\
\text { o njegovi } \\
\text { vsebini } \\
\text { pogovarjam } \\
\text { z drugimi. }\end{array}$ & $\begin{array}{c}\text { Podčrtam } \\
\text { pomembne } \\
\text { dele } \\
\text { besedila. }\end{array}$ & $\begin{array}{l}\text { S svojimi } \\
\text { besedami } \\
\text { povzamem } \\
\text { besedilo. }\end{array}$ & $\begin{array}{c}\text { Besedilo } \\
\text { na glas } \\
\text { preberem } \\
\text { nekomu } \\
\text { drugemu. }\end{array}$ \\
\hline $\begin{array}{l}\% \text { dijakov in dija- } \\
\text { kinj }(2009)\end{array}$ & 22,7 & I 4,2 & 27,2 & 48,0 & 53,0 & 19,3 \\
\hline Bralni dosežek* & 492 & 475 & 516 & 510 & 513 & 482 \\
\hline $\begin{array}{l}\text { \% dijakov in dija- } \\
\text { kinj (20I8) }\end{array}$ & 22,7 & 17,3 & $3 \mathrm{I}, 7$ & 44,8 & 51,2 & 23,5 \\
\hline Bralni dosežek* & 495 & 500 & $53 \mathrm{I}$ & $52 \mathrm{I}$ & 523 & 506 \\
\hline
\end{tabular}

Opomba: * Gre za povprečni dosežek tistih dijakov in dijakinj, ki so strategijo ocenili $\mathrm{z} \gg$ uporabno $\ll$ in $\mathrm{z} \gg z$ zelo uporabno «; Povprečni dosežek za Slovenijo pri branju je leta 2009 znašal 483 točk (OECD 494 točk), leta 2018 pa 495 točk (OECD 487 točk).

Zaradi večje preglednosti v tabeli ne navajamo vrednosti standardnih odklonov. Ta podatek je dostopen v pripadajoči tabeli na naslednji povezavi pod zavihkom Codebook and Compendia: https://www.oecd.org/pisa/data/2018database/. 
Tabela ı: Ocena uporabnosti pogovarjanja o prebranem z drugimi: razlike po spolu znotraj posameznega izobraževalnega programa v letu 2018.

\begin{tabular}{|c|c|c|c|c|c|}
\hline & & \multicolumn{4}{|c|}{ Pogovarjanje o prebranem } \\
\hline & & $M$ & $S D$ & $t(\mathrm{df})$ & $p$ \\
\hline \multirow{2}{*}{ Splošna in klasična gimnazija } & Dijaki & 3,64 & $\mathrm{I}, 47$ & & \\
\hline & Dijakinje & 4,33 & $\mathrm{I}, 43$ & $7,23(1380)$ & *** \\
\hline \multirow{2}{*}{ Strokovna gimnazija } & Dijaki & 3,77 & $\mathrm{I}, 50$ & & \\
\hline & Dijakinje & 4,09 & $\mathrm{I}, 45$ & $2,55(633)$ & **** \\
\hline \multirow{2}{*}{ Srednje strokovno izobraževanje } & Dijaki & 3,35 & 1,54 & & \\
\hline & Dijakinje & 3,69 & 1,54 & $4,70(2507)$ & **** \\
\hline \multirow{2}{*}{ Srednje poklicno izobraževanje } & Dijaki & 2,87 & 1,50 & & \\
\hline & Dijakinje & 3,22 & 1,52 & $2,97(1348)$ & $* * *$ \\
\hline
\end{tabular}

Opomba: Dijaki in dijakinje so postavko ocenili na lestvici od I do 6, kjer I pomeni, da se jim ta bralna strategija sploh ne zdi uporabna, 6 pa, da se jim zdi zelo uporabna; $M$ - aritmetična sredina; $S D$ - standardni odklon; $t$ - t test; $d f$ - stopnje svobode; $p$ - stopnja tveganja: ${ }^{* * *} \mathrm{p} \leq, \mathrm{OOI}$.

\section{Metakognitivne bralne strategije: povzemanje besedila}

Poleg metakognitivnih bralnih strategij razumevanja in pomnjenja besedila so dijaki in dijakinje $\mathrm{v}$ obeh ciklih raziskave ocenili tudi uporabnost metakognitivne bralne strategije povzemanja besedila. V primerjavi z letom 2009 (Tabela 13 ) so dijaki in dijakinje v ciklu raziskave PISA 2018 večino strategij povzemanja besedila (razen pisanja povzetka in preverjanja povzete vsebine) ocenili kot manj uporabne, iz mednarodnega poročila raziskave PISA 2018 (OECD, $2019 \mathrm{~b}$ ) pa je razvidno, da so razlike v odstotnih deležih med leti 2009 in 2018 statistično značilne.

Podobno kot leta 2009 so leta 2018 kot najuporabnejši strategiji povzemanja besedila ocenili preverjanje tega, ali so v povzetku predstavljena najpomembnejša dejstva, in podčrtavanje najpomembnejših dejstev ter pisanje lastnega povzetka na podlagi teh dejstev. Dijaki in dijakinje, ki so omenjeni bralni strategiji ocenili kot najuporabnejši, so v obeh ciklih raziskave v povprečju dosegli tudi najvišje dosežke na preizkusu iz bralne pismenosti PISA.

Podobno, kot se je pokazalo pri oceni bralnih strategij razumevanja in pomnjenja besedila, so tudi uporabnost strategije, ki se nanaša na podčrtavanje najpomembnejših delov besedila in pisanje lastnega povzetka iz teh delov, najvišje ocenili dijaki in dijakinje, ki obiskujejo gimnazijske programe, najnižje pa dijaki in dijakinje iz srednjih poklicnih šol. V vseh 
izobraževalnih programih so uporabnost te strategije povzemanja besedila v povprečju najvišje ocenile dijakinje, razlika med spoloma pa se je tudi tukaj v vseh izobraževalnih programih pokazala kot statistično značilna.

Tabela I2: Odstotek dijakov, ki so ocenili, da se jim zdi določena strategija pri pisanju povzetka dalǰ̌sega besedila »uporabna « ali »zelo uporabna«, ter njihovi povprečni bralni dosežki: primerjava med leti 2009 in 2018.

\begin{tabular}{|c|c|c|c|c|c|}
\hline & $\begin{array}{c}\text { Napišem } \\
\text { povzetek. Nato } \\
\text { preverim, ali je } \\
\text { vsak odstavek } \\
\text { vključen v } \\
\text { povzetek, } \\
\text { ker mora biti } \\
\text { vključena } \\
\text { vsebina vsakega } \\
\text { odstavka. }\end{array}$ & $\begin{array}{l}\text { Pravilno } \\
\text { poskušam } \\
\text { prepisati čim } \\
\text { več stavkov. }\end{array}$ & $\begin{array}{c}\text { Preden } \\
\text { napišem } \\
\text { povzetek, } \\
\text { čim večkrat } \\
\text { preberem } \\
\text { besedilo. }\end{array}$ & $\begin{array}{c}\text { Natančno } \\
\text { preverim, ali } \\
\text { so v povzetku } \\
\text { predstavljena } \\
\text { najpomembnejša } \\
\text { dejstva. }\end{array}$ & $\begin{array}{c}\text { Preberem } \\
\text { besedilo in } \\
\text { podčrtam } \\
\text { najpomembnejše } \\
\text { stavke. Nato jih s } \\
\text { svojimi besedami } \\
\text { napišem kot } \\
\text { povzetek. }\end{array}$ \\
\hline $\begin{array}{l}\% \text { dijakov in dija- } \\
\text { kinj }(2009)\end{array}$ & 24,5 & $\mathrm{I} 4,5$ & 38,0 & 50,0 & 53,5 \\
\hline Bralni dosežek* & 501 & $45^{2}$ & 507 & 518 & 509 \\
\hline $\begin{array}{l}\text { \% dijakov in dija- } \\
\text { kinj (20I8) }\end{array}$ & 25,0 & $\mathrm{I} 2,4$ & 31,6 & 42,9 & 44,9 \\
\hline Bralni dosežek ${ }^{*}$ & 518 & 470 & 521 & 533 & $52 \mathrm{I}$ \\
\hline
\end{tabular}

Opomba: Gre za povprečni dosežek tistih dijakov in dijakinj, ki so strategijo ocenili $z$ »uporabno « in $\mathrm{z} » z$ zelo uporabno «; Povprečni dosežek za Slovenijo pri branju je leta 2009 znašal 483 točk (OECD 494 točk), leta 2018 pa 495 točk (OECD 487 točk).

Zaradi večje preglednosti v tabeli ne navajamo vrednosti standardnih odklonov. Ta podatek je dostopen v pripadajoči tabeli na naslednji povezavi pod zavihkom Codebook and Compendia: https://www.oecd.org/pisa/data/2or8database/. 
Tabela I3: Ocena uporabnosti podčrtavanja najpomembnejših delov besedila in pisanja lastnega povzetka: razlike po spolu znotraj posameznih izobraževalnih programov v letu 2018.

\begin{tabular}{|c|c|c|c|c|c|}
\hline & & \multicolumn{4}{|c|}{$\begin{array}{c}\text { Podčrtavanje najpomembnejših delov } \\
\text { besedila in pisanje lastnega povzetka iz teh } \\
\text { delov }\end{array}$} \\
\hline & & $M$ & $S D$ & $t(d f)$ & $p$ \\
\hline \multirow{2}{*}{ Splošna in klasična gimnazija } & Dijaki & 3,92 & $\mathrm{I}, 52$ & & \\
\hline & Dijakinje & 4,79 & 1,30 & $9,80(1374)$ & $* * *$ \\
\hline \multirow{2}{*}{ Strokovna gimnazija } & Dijaki & 4,00 & $\mathrm{I}, 43$ & & \\
\hline & Dijakinje & 4,80 & 1,33 & $6,63(630)$ & *** \\
\hline \multirow{2}{*}{ Srednje strokovno izobraževanje } & Dijaki & 3,84 & 1,56 & & \\
\hline & Dijakinje & 4,42 & $\mathrm{I}, 4 \mathrm{O}$ & $8,53(250 \mathrm{I})$ & *** \\
\hline \multirow{2}{*}{ Srednje poklicno izobraževanje } & Dijaki & 3,18 & I,6I & & \\
\hline & Dijakinje & 3,89 & 1,55 & $6,26(1344)$ & $* * *$ \\
\hline
\end{tabular}

Opomba: Dijaki in dijakinje so postavko ocenili na lestvici od I do 6, kjer I pomeni, da se jim ta bralna strategija sploh ne zdi uporabna, 6 pa, da se jim zdi zelo uporabna; $M$ - aritmetična sredina; $S D$ - standardni odklon; $t$ - t test; $d f$ - stopnje svobode; $p$ - stopnja tveganja: ${ }^{* * *} \mathrm{p} \leq, \mathrm{OOI}$.

\section{Zaključki}

$\mathrm{V}$ prispevku sva na podlagi podatkov raziskav PISA 2009 in 2018 ugotavljali razlike $v$ motivaciji za branje, pogostosti branja določene vrste gradiv, pogostosti branja na spletu in oceni učinkovitosti metakognitivnih bralnih strategij pri slovenskih dijakih in dijakinjah prvih letnikov. Ker se skozi vse cikle raziskave PISA pri bralnih dosežkih in motivaciji za branje kažejo značilne razlike med spoloma, sva preučili tudi te, in sicer znotraj posameznih srednješolskih izobraževalnih programov.

Primerjalna analiza podatkov je pokazala, da so dijaki in dijakinje, $v$ primerjavi z letom 2009 , leta 2018 poročali o manj pogostem branju za zabavo in uživanju v branju, kot manj uporabne so ocenili tudi metakognitivne strategije povzemanja besedila, poročali pa so o pogostejšem iskanju informacij na spletu in nekoliko pogostejšem poseganju po leposlovnih gradivih. Slednje velja predvsem za dekleta, ki so v primerjavi s fanti v vseh izobraževalnih programih poročala tudi o večji motivaciji za branje, nisva pa znotraj nobenega izobraževalnega programa ugotovili razlik med spoloma v branju na spletu.

Na podlagi izsledkov lahko zaključiva, da na področju branja po desetih letih v Sloveniji še vedno ostaja izziv, kako pri mladostnikih krepiti zanimanje za branje, saj je $z$ vidika splošne bralne pismenosti mladih in 
njihove učne uspešnosti pomembno, da branje sprejmejo kot nekaj, kar radi počnejo v prostem času. Poleg tega izziv še vedno ostaja tudi spodbujanje socialnega konteksta branja $\mathrm{v}$ mladostniškem obdobju (npr. razprave o prebranem, vrstniško delo v skupini, izražanje mnenja o prebranem). Ker je mladim v tem obdobju pomembno druženje $\mathrm{z}$ vrstniki in uveljavljanje v vrstniški skupini, je to lahko pristop, ki spodbuja njihovo motivacijo za branje (Puklek Levpušček et al., 20I2). Kot pomanjkljiva se še vedno kažeta tudi poznavanje in uporaba različnih metakognitivnih bralnih strategij. Iz tega sledi, da je pomembno načrtno ozaveščanje mladih o tem, katere bralne strategije so uporabne pri poglobljenem branju in razumevanju različnih učnih vsebin. $\mathrm{Na}$ ta način učenci tudi bolje ozavestijo lasten učni proces in nad njim vzpostavijo nadzor, kar se kasneje lahko odrazi tudi v večji zaznani lastni kompetentnosti pri branju in veselju do branja (Nurmi et al., 2003). V zadnjih desetih letih je bil v Sloveniji pod okriljem Zavoda RS za šolstvo (ZRSŠ) v sodelovanju s Pedagoškim inštitutom izveden večji projekt, katerega namen je bil opolnomočiti učence za izboljšanje bralne pismenosti in samoregulacije učenja, spodbuditi aktivno vlogo učencev $\mathrm{v}$ procesu izgrajevanja bralnih kompetenc in bralnega razumevanja ter razviti spretnosti kritičnega branja (npr. Nolimal et al., 20I4). V omenjenem projektu avtorji sistematično razvijajo ciljno usmerjene strategije dela na področju bralne pismenosti, izvajalci pa izvajajo aktivnosti neposredno z učenci (npr. aktivnosti spodbujanja motivacije za branje, razvoja tehnik branja in refleksije učencev o lastnem branju in delu). Zato so tovrstni projekti gotovo dobrodošli in z evalvacijami tudi dokazujejo, da so lahko uspešni (ibid.). Na žalost pa je njihovo trajanje omejeno na čas financiranja projekta, zato se lahko izničijo njihovi dolgoročni učinki, vprašljivo pa je tudi, v kolikšni meri na šolah še naprej (v naslednjih generacijah in letih) izvajajo aktivnosti opolnomočenja učencev na področju bralne pismenosti in motivacije za branje, ki so se $\mathrm{v}$ projektu izkazale kot uspešne.

Glede na to, da izsledki primerjalne analize kažejo na vse pogostejše branje mladih na spletu, ki se, ne glede na vrsto bralne aktivnosti, povezuje z nadpovprečnimi bralnimi dosežki na preizkusu PISA, v bralnih aktivnostih pa ne zaznavamo razlik med spoloma v nobenem od izobraževalnih programov, vidiva kot pomembno sredstvo za krepitev bralne motivacije in spodbujanje pogostosti branja $\mathrm{v}$ ustvarjanju kakovostnih spletnih učnih gradiv za učence in dijake. $V$ zadnjih letih je na voljo že precej tovrstnih učnih gradiv, v obliki elektronskih in interaktivnih učbenikov, delovnih zvezkov in vaj, izobraževalnih spletišč in interaktivnih učnih okolij, tako v prosto dostopni kot plačljivi obliki. Če so jih prej uporabljali predvsem učitelji, ki so imeli razvite digitalne kompetence in so želeli pri 
učencih ter dijakih razvijati tudi digitalno pismenost, je bil čas razglasitve epidemije Covid-ıs in prehod na izobraževanje na daljavo v marcu 2020 verjetno prelomni trenutek v zgodovini izobraževanja. Zgodila se je namreč vsesplošna uporaba digitalne učne tehnologije, ki je zahtevala od pedagoških delavcev hitro prilagoditev na novo digitalno stvarnost poučevanja. $\mathrm{Na} Z$ ZRSŠ so maja in junija 2020 izvedli obsežno raziskavo Izobraževanje na daljavo v času epidemije Covid-rg v Sloveniji, v kateri je sodelovalo nekaj manj kot tretjina vseh učiteljev osnovnih in srednjih šol, desetina učencev in dijakov ter dve tretjini ravnateljev (Rupnik Vec et al., 2020). Iz poročila raziskave sicer ni razbrati, ali so učitelji pri svojem delu na daljavo uporabljali tudi spletna učna gradiva in katera, so pa rezultati v starejših skupinah učencev (predmetni pouk OŠ, srednja šola) pokazali, da so izdelki, ki so jih učitelji zahtevali od učencev in dijakov, predvsem izpolnjeni učni listi, rešene naloge $\mathrm{v}$ delovnem zvezku, krajši pisni povzetki ter, predvsem to velja za dijake, pisni odgovori na kompleksnejša vprašanja iz obravnavane učne vsebine. Učitelji so torej v času epidemije verjetno še vedno uporabljali predvsem tradicionalna (pisna) učna gradiva in zahtevali pri preverjanju znanja izdelke in naloge, kot bi jih tudi sicer v razredu, le da so jih učenci in dijaki sedaj posredovali učitelju prek elektronske pošte ali spletne učilnice. Inovativna uporaba digitalne izobraževalne tehnologije bo verjetno $\mathrm{v}$ prihodnosti zahtevala večjo sistemsko usmerjenost $\mathrm{k}$ sistematičnemu izdelovanju kakovostnih spletnih učnih gradiv po celotni izobraževalni vertikali s primerno uravnoteženostjo strokovne ustreznosti in zahtevnosti učnih vsebin, upoštevanjem predznanja učencev ter didaktično ustreznim vključevanjem elementov multimedijskosti in interaktivnosti, ki bodo, vsaj v določeni meri, vključena v proces usvajanja učne snovi ter preverjanja in ocenjevanja znanja vseh učencev in dijakov. Pri tem je pomembno, da spletna učna gradiva s pomočjo kognitivnih in metakognitivnih učnih opor (angl. scaffolding) napotujejo učence in dijake na ustrezno razumevanje prebranega, ugotavljanje bistvenega, refleksijo o naučenem, omogočajo neposredne povratne informacije o ravni znanja ipd., kar bo tudi v digitalnem učnem okolju (v kombinaciji s tradicionalnimi tiskanimi učnimi gradivi) omogočalo boljši razvoj bralne pismenosti.

\section{Literatura}

Guthrie, J., Schafer, W., in Huang, C. (200I) Benefits of opportunity to read in balanced instruction on the NAEP. The Journal of Educational Research 94 (3), I 45-162.

Nolimal, F., Cankar, G., Doupona, M., Marentič Požarnik, B., Pečjak, S., in Potočnik, N. (2014) Opolnomočenje učencev z izboljšanjem 
bralne pismenosti in dostopa do znanja (evalvacijsko poročilo projekta). Spletna stran: https://www.zrss.si/pdf/Evalvacijsko-porocilo-bralnapismenost-2014.pdf (pridobljeno I0. 8. 2020).

Nurmi, J. E., Aunola, K., Salmela-Aro, K., in Lindroos, M. (2003) The role of success expectation and task-avoidance in academic performance and satisfaction: Three studies on antecedents, consequences and correlates. Contemporary Educational Psychology 28, str. 59-90.

OECD. (2010) PISA 2009 Results: Learning to learn: Student engagement, strategies and practices (Volume III). Pariz: OECD Publishing.

OECD. (2015) Universal basic skills: What countries stand to gain. Pariz: OECD Publishing.

OECD. (2019a) PISA 2018 assessment and analytical framework. Pariz: OECD Publishing.

OECD. (2019b) PISA 2018 results: What school life means for student's lives (Volume III). Pariz: OECD Publishing.

OECD. (2020) PISA 2018 technical report. Pariz: OECD Publishing. Spletna stran: https://www.oecd.org/PISA20I8_Technical-Report.pdf(pridobljeno 20. 6. 2020).

Puklek Levpušček, M., Podlesek, A., in Šterman Ivančič, K. (2012) Dejavniki bralne pismenosti v raziskavi PISA 2009. Ljubljana: Pedagoški inštitut.

Puklek Levpušček, M. in Šterman Ivančič, K. (ur.) (2013) Motivacijski dejavniki v izobraževanju mladine in odraslih. Ljubljana: Pedagoški inštitut.

Rupnik Vec, T., Slivar, B., Zupanc Grom, R., Preskar, S., Mithans, M., Kregar, S., Ivanuš Grmek, M., Bevc, V., Holcar Brauner, A., in Musek Lešnik, K. (2020) Analiza izobraževanja na daljavo v času epidemije Covid-Ig v Sloveniji (delno poročilo). Spletna stran: https://www.zrss. si/digitalnaknjiznica/IzobrazevanjeNaDaljavo/2/\#zoom=z (pridobljeno I2. 8. 2020).

Sullivan, A. in Brown, M. (2015) Reading for pleasure in progress in vocabulary in mathematics. British Educational Research Journal 4I/6, str. 97I-991.

Šterman Ivančič, K. (2017) Motivacijski dejavniki naravoslovnih dosežkov v raziskavi PISA 2015: razlike po izobraževalnem programu in spolu. V Sardoč, M., Ž. Žagar. I., in Mlekuž, A. (ur.). Raziskovanje v vzgoji in izobraževanju danes: zbornik povzetkov: 2. nacionalna znanstvena konferenca, Ljubljana, 25. september 2017. Ljubljana: Pedagoški inštitut.

Šterman Ivančič, K. (2019) PISA 20I8: Nacionalno poročilo s primeri nalog iz branja. Ljubljana: Pedagoški inštitut. 
Štraus, M. (2010) OECD PISA 200g: Prvi rezultati. Ljubljana: Pedagoški inštitut. Spletna stran: https://www.pei.si/wp-content/uploads/2018/r2/ PISA2009_prviRezultati.pdf(pridobljeno 21. 5. 2020).

Štraus, M., Repež, M., in Štigl, S. (2007) Nacionalno poročilo PISA 20o6: naravoslovni, bralni in matematični dosežki slovenskih učencev. Ljubljana: Pedagoški inštitut.

Štraus, M., Šterman Ivančič, K., in Štigl, S. (2013) OECD PISA 20I2: Prvi rezultati. Ljubljana: Pedagoški inštitut. Spletna stran: https://www.pei. si/wp-content/uploads/2018/12/PISA-2012-Povzetek-rezultatov-SLO. pdf (pridobljeno 2I. 5. 2020).

Štraus, M., Šterman Ivančič, K., in Štigl, S. (2017) PISA 2015: Nacionalno poročilo strendi dosežkov med leti 2006, 2012 in 2015 ter primeri naravoslovnih nalog. Ljubljana: Pedagoški inštitut. 